
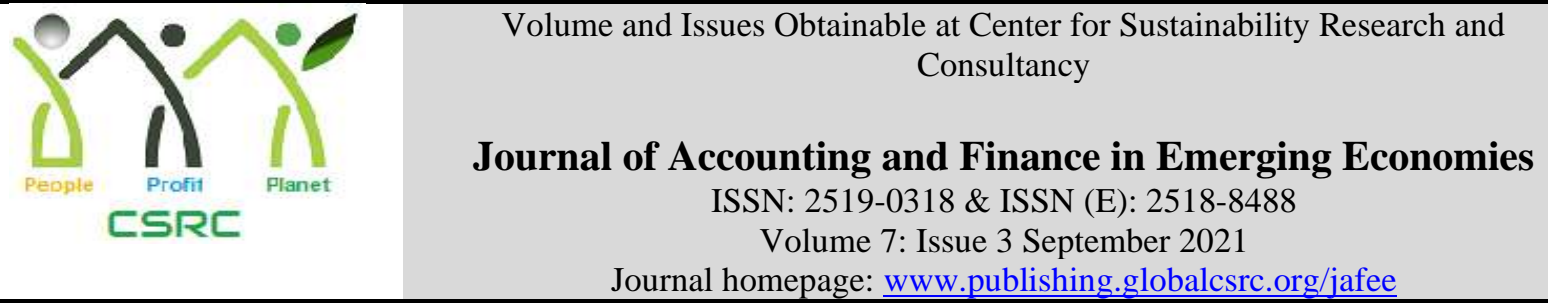

\title{
Significance of Financial and Non Financial Information on Credit Rating: An Empirical Study on Banking and Insurance Sectors of Pakistan
}

*Muhammad Khalid Rashid, Government College of Science, Lahore, Pakistan

Muhammad Noor ul Haq, School of Accountancy \& Finance, The University of Lahore,

Lahore, Pakistan

Umair Khalid, School of Accountancy \& Finance, The University of Lahore, Lahore, Pakistan

Abdul Basit, Lahore Institute of Science \& Technology, Lahore, Pakistan

*Corresponding author's email address: krkhan55@ hotmail.com

\begin{tabular}{l}
\hline ARTICLE DETAILS \\
\hline History \\
Revised format: Aug 2021 \\
Available Online: Sep 2021
\end{tabular}

Keywords

Financial and non-financial

Sector, Credit Rating,

Financial and non-financial

Information

JEL Classification

G23, G32

\begin{abstract}
Purpose: Apart from standard spheres of financial institutions' performance such as asset quality, profitability, liquidity and efficiency; the study investigates the influence of non-financial factors such as governance and management.

Design/Methodology/Approach: This study utilizes 2009 through 2018 data for the sample of commercial banks and insurance companies of Pakistan to analyze the significance of financial and non-financial information on credit rating. The study is done by employing frequently used Fully Modified Ordinary Least Square (FMOLS).

Findings: The main contribution lies including explanatory variables from various areas that have an impact on the financial position of the examined banks and insurance companies.

Implications/Originality/Value: The obtained results suggest that the combined use of financial and non-financial information tends to a significant impact on credit rating.
\end{abstract}

(C) 2021 The authors, under a Creative Commons Attribution-

NonCommercial 4.0

Recommended citation: Rashid, M. K., Haq, M. N., Khalid, U. and Basit, A. (2021). Significance of Financial and non Financial Information on Credit Rating: An Empirical Study on Banking and Insurance Sectors of Pakistan. Journal of Accounting and Finance in Emerging Economies, 7 (3), 757-765.

\section{Introduction}

Credit risk is a risk of failure, it may be discussed as the possible risk that a borrower or counterparty will neglect to meet its obligations in accordance with agreed terms. Credit risk is also defined as the risk of loss or to be a loss that may occur from the default or failure of any contractual party to obey the terms and conditions of any financial contract, principally the failure to make required payments on loans including the earnings due to an entity. The risk is a representation of an uneven expectation of loss or variation in the return of any given asset. 
The history of credit risk revealed the history of lending or borrowings activities itself and also cleared the birth of the concept of insurance since 1300 B.C. Caouette et al. (1998) mentioned about the most ancient risk of the financial market. The authors explained the history of credit risk and explained that the credit risk has an existence earlier of 1800 B.C. Kohn (1999) also explained that risk came back with the merchant bank and then bore the risk by bill of exchange through funding. The more or less main concern for the traditional banking system was the credit risk since its inception and concept evolved. However, then the banking system becomes more advance and involved in the relationship side to promote the business rather than the concentration in profitability.

The current study consists of a comprehensive sample data of commercial banks and insurance companies operated in Pakistan with their assigned ratings. The study demonstrates the whole research on the banking and insurance sector of Pakistan because of its unique significance. In recent years a number of studies dealing with the ratings of financial and corporate industries however minority of them are related to the credit rating of banking and insurance sectors in this region under the same topic and utilization of information collectively. As far as the economic instability, political intervention in each institute and a hike of corruption makes great differences. Banks need some insurance to secure their business and depositors and insurance companies also need investment and reinsurance companies in this type of squeeze environment. So, the study will helpful for Pakistan's banks and insurance companies in the current situation to manage their businesses.

\section{Literature Review}

Adams et al. (2003) reported that the credit rating determinants can suggest the regulators, policymakers, investors and the market leaders decide the reliability of assigned credit ratings. The CRAs issued some specific guidelines to give an overview of their credit rating assessment of different categories on which the credit rating decision depends. These measures are included quantitative and qualitative measures like asset quality, management, ownership structure, business and financial risks, capital adequacy, business strategy, business leverage, liquidity and funding, market overview, the regulatory environment and all the relative factors of the risk assessment that directly and indirectly affect the creditworthiness of the institution.

Hammer et al. (2012) examined the performance of the banks by using absolute values of 14 accounting variables and 9 representative financial ratios. All the ratios described the asset quality, profit \& cost efficiency and liquidity of the institution. The author concluded the performance of those areas which had an impact on the bank's performance and has strong intervention power. Paula et al., (2018) investigated the impact of financial variables on the firm's credit rating. The authors revealed that the firm's management used its earnings and operational returns to retain ratings rather than the downgrades. The authors concluded that all the variables have their own impact but the association of operational return and the firm's earnings are more relevant to the creditworthiness of the firm.

Cornett et al. (2009) examined that there was a positive relationship between the institutional performance and the various corporate practices like independence of board of director. The authors conducted the study by taking a sample of 300 public-traded USA banks for the examination of the respective corporate governance and performance of the public banks. The authors concluded the results that if the sponsors increase the ownership and increase the independence in the board then the bank can perform more efficiently.

Erkens et al. (2012) and Beltratti and Stulz (2012) investigated the relationship between corporate governance and institutional performance. The study found that the performance of the firms was 
adversely affected by their high institutional back support and stake due to the more risk-taking before the big financial crises. After that, the same firms could not make the proper dealing that's hurt in the big crises and strongly affected the performance of the firms.

Liao et al. (2017) observed that credit rating agencies give more preference to the non-financial factors when evaluating the creditworthiness of any firm and issued good ratings to the clients that hold major market share relative to the others.

\section{Research Methodology}

\section{Conceptual Framework}

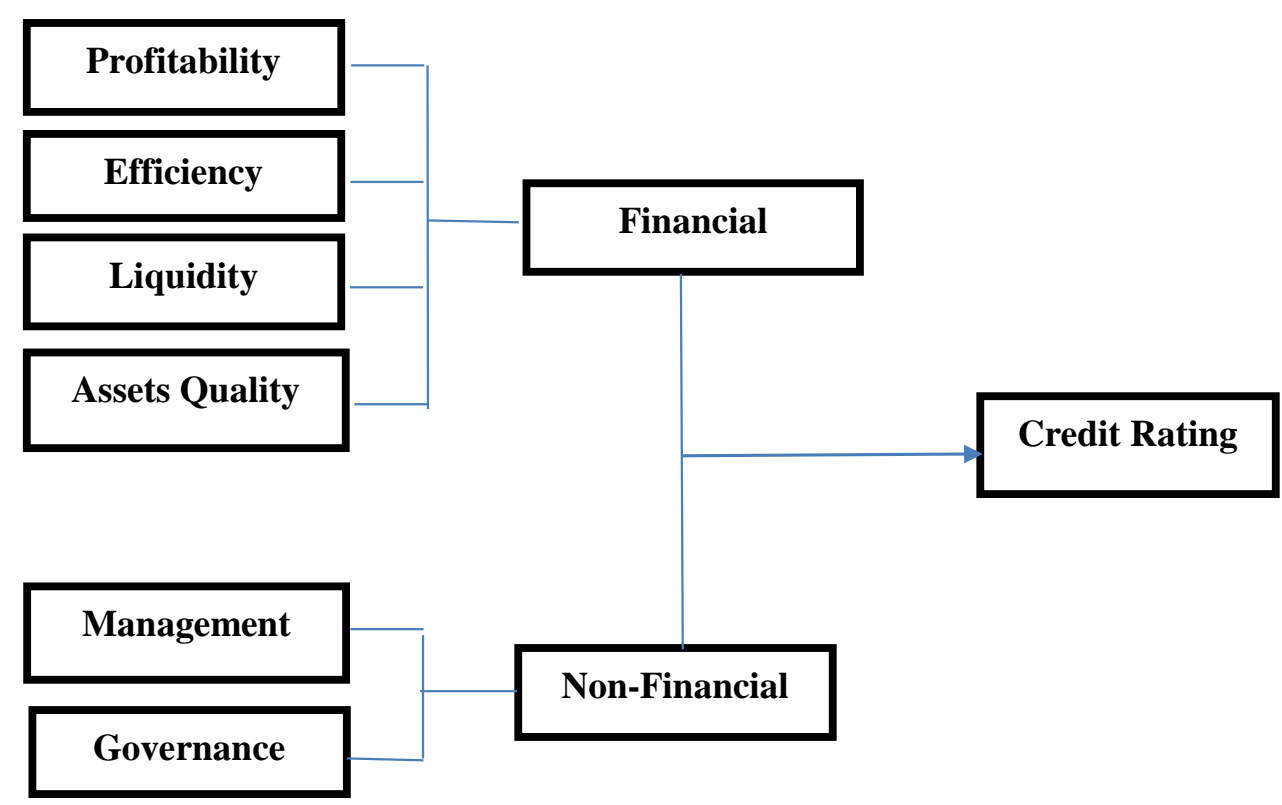

\section{Hypothesis Development}

H1: There is an association between bank non-financial determinants and the credit rating.

$\mathrm{H} 2$ : There is an association between bank financial determinants and the credit rating.

$\mathrm{H} 3$ : There is an association exists between non-financial determinants and the IFS rating.

$\mathrm{H} 4$ : There is an association exists between financial determinants and the IFS rating.

\section{Criteria of Sample Data}

According to Ilker Etikan et al. (2016), in each type of research, it would be remarkable to use the population but in many cases, it is not possible to include each subject because the whole population is almost finite. This is the rationale behind using sampling techniques like convenience sampling by most researchers. Convenience sampling adopted in this study and the banking and insurance sectors of Pakistan is selected. Therefore, the sample of the study is taken from both sectors in the region of Pakistan. Scheduled Banks (other than foreign banks) and insurance companies (including general and life) operating in Pakistan are selected for the analyses.

\section{Source of Data and Data Collection}

In this study, seven variables are used, six independent variables including financial and nonfinancial determinants and the one is the dependent variable. The researcher used secondary data to conduct the study. The data for the study is collected from the financial statements and CRAs rating reports of each financial institution. The total dataset consists of over ten years, from 2009 to 2018. The number of observations of the study are 140 . However, there is a little bit variation in the accounting of observations according to the availability of information. 


\section{Fully Modified Ordinary Least Square (FMOLS)}

Kao and Chiang (2000) suggested the FMOLS technique. This technique was supported to statistically estimate the panel co-integration. With the support of this technique, the author can estimate standard pooled OLS which is helpful for endogeneity and auto-correlation of regressors. Following is the fixed effect regression equation and with its help it can be discussed:

$$
\begin{gathered}
y_{i t}=\alpha_{i}+X_{i t} \beta+\mu_{i t} \\
i=1, \ldots \ldots \ldots, N .
\end{gathered}
$$

where:

$y_{i t}$; denotes matrix of the order $(1,1)$

$\beta$; denotes the vector of slopes show having a dimension $(\mathrm{k}, 1)$

$\alpha_{i}$; denotes individual a fixed effect

$u_{i t}$ is the disturbance or error terms.

In this FMOLS model, it is assumed that $x_{i t}(\mathrm{k}, 1)$ having dimension vectors are integrated for all $I$ of order 1.

$$
x_{i t}=x_{i t}-1+\varepsilon_{i t}
$$

With the respective specifications, a model of co-integrated regression is utilized to show the relationship between the two parameters $y_{i t}$ and $x_{i t}$. The normality of the distribution is checked through the evaluation of FMOLS estimators. The FMOLS estimators can be written as:

where:

$$
B_{F M O L S}=\left[\sum_{i=1}^{N} \sum_{i=1}^{T}(x i t=x i)\right]-1\left[\sum_{i=1}^{N}\left(\sum_{i=1}^{T}(x i t-x i) y_{i t}^{+}+T y \triangle_{\epsilon \mu}^{+}\right)\right.
$$

$\Delta^{+}{ }_{\varepsilon \mu}$ denotes the term of auto correlation and $y_{i t}{ }^{+}$denotes the transformed variable which comes from $y_{i t}$ to estimate the endogeneity correction.

The co-integrating panel regressions are maybe part of FMOLS. So that the importance of this FMOLS technique was used to check the long-run relationship in the study among the applied variables.

\section{Description of Variable Dependent Variables}

The dependent variable of the study is credit rating assigned by both of the CRAs - PACRA and JCR-VIS period of the interest are then 2009 - 2018. As the main interest of the study is generally depend on inflective determinants of credit ratings, therefore it doesn't matter that which CRA assigns the ratings.

\section{Credit Rating}

Gujarati (2006) stated that ordinal variable is the variables of different categories which are represented by the degree of ranking like a variable shows the degree of satisfaction. Every bank and insurance company is assigned rating by CRA within a specified time period.

\section{Independent Variables}

\section{Asset Quality}

Non-performing loans can be defined as the loan that is not performing or the principal amount is unrecoverable with its due interest amount. A loan is non-performing when the payments are due to interest and principle by 90 days or more. The credit risk of solvency is originate from the asset quality of that institution. The asset quality of any commercial bank is analyzed through the 
advances portion and the loan loss provision. This is measured as the ratio of non-performing loans to total loans.

\section{Efficiency}

The efficiency ratio is calculated by dividing operating cost to operating income. According to Mensah et al. (2017), efficiency denotes the average ratio of cost to income. Cocheo (2000) inducted that public banks considered the efficiency ratio as a benchmark, others also show concerns but a less than the others.

\section{Governance}

The measurement tool of corporate governance is comprises on the assessment of the size of the board, members profile, board effectiveness and quality of governance framework. Financial Institutions are structurally very complex and opaque in terms of their internal operations and disclosure, thus increasing the level of information asymmetry between shareholders and management.

\section{Liquidity}

Financial performance of any bank can be measured through the funding line that a bank manages to meet the obligations without any big deposit base. According to Mensah et al. (2017), liquidity presents the average ratio of liquid assets to deposits and short-term funding.

\section{Management}

The assessment of management starts with conducting an in-depth analysis of organizational structure, analysis of management, management effectiveness, management information system and effectiveness of the risk management function of the entity. The elements included in quality management (e.g. professional experience, technical knowledge, analytical skills, the integrity of the company, personal honesty, eagerness to ensure a good reputation and maintained regulated environment and powers to implement plans effectively), which is a qualitative measure in the credit rating risk evaluation analysis.

\section{Profitability}

Profitability is proxies with return on asset (ROA) of the institution, where ROA is measured as the ratio of net income to total assets. According to Shen et al. (2012), ROA tells how effective banks' resources in achieving objectives and every institution have an objective to maximize the financial strength of entity for the shareholder's worth.

\section{Empirical Test and Results}

\section{Bank's Non-Financial Variables Analysis with Respect to Credit Rating}

Adjusted R square is 0.8287 which is much significant. Which shows the explanatory power of the model. Two qualitative variables in the model are included, both are significant at $5 \%$ level of significance.

Table 1: Bank's Non-Financial Variables Analysis with Respect to Credit Rating

\begin{tabular}{lcccc}
\hline \hline Variable & Coefficient & Std. Error & t-Statistic & Prob. \\
\hline \hline GOVERNANCE & 0.218813 & 0.087759 & 2.493324 & 0.0148 \\
MANAGEMENT & 0.169337 & 0.049609 & 3.413448 & 0.0010 \\
\hline \hline R-squared & 0.837505 Adjusted R-squared & 0.828692
\end{tabular}


The estimated results in table 1 show that both of the non-financial variables governance and management are significant at $95 \%$ level of confidence which confirm the importance of their induction in the model. Therefore the null hypothesis $\left(\mathrm{H}_{0}\right)$ is rejected in the favor of these significant and positive coefficients. Considering results of the analysis it may claim that governance with a coefficient value of 0.2188 more contributing than management with a coefficient value of 0.1693 .

\section{Bank's Financial Variables Analysis with Respect to Credit Rating}

The value of adjusted $\mathrm{R}$ square is 0.8318 which is significant and shows the explanatory power of the model. There are four quantitative variables in this empirical model, almost all are positively significant at a $95 \%$ confidence interval shows in table 4.2 Significant and positive correlation with all determinants suggests that the hypothesis is supported by the data. The most contributing turned out to be profitability with a coefficient value of 14.6616, asset quality with a coefficient value of 4.3276 , followed by liquidity with coefficient value of 1.6289 and efficiency with a coefficient value of 0.5894 of the banks. The results also proved that if these variables include in the credit risk assessment, the chances of a better credit rating are increased for banks.

Table 2: Bank's Financial Variables Analysis with Respect to Credit Rating

\begin{tabular}{lllll}
\hline \hline Variable & Coefficient & Std. Error & t-Statistic & Prob. \\
\hline \hline ASSETQUALITY & 4.327605 & 0.976492 & 4.431787 & 0.0000 \\
EFFICIENCY & 0.589362 & 0.223019 & 2.642652 & 0.0100 \\
LIQUIDITY & 1.628944 & 0.531282 & 3.066063 & 0.0030 \\
PROFITABILITY & 14.66157 & 6.971300 & 2.103133 & 0.0388 \\
\hline \hline R-squared & 0.841651 & Adjusted R-squared & 0.831670 \\
\hline \hline
\end{tabular}

\section{Insurance Non-financial variables Analysis with respect to Credit Rating}

The results in table 3 show that the significant value of adjusted $\mathrm{R}$ square is 0.8517 which shows the explanatory power of the model in this study. Both of the two qualitative variables are significant at a $95 \%$ confidence interval which is included in the model.

As well as in the respective hypothesis the obtained results reveal that the implied assumptions are considered well. Governance and management are the most significant non-financial determinants. It also confirmed that an insurance company can observe a high rating if it includes better management with good governance.

Table 3: Insurance Non-Financial Variables Analysis with Respect to Credit Rating

\begin{tabular}{lllll}
\hline \hline Variable & Coefficient & Std. Error & t-Statistic & Prob. \\
\hline \hline GOVERNANCE & 0.487684 & 0.066867 & 7.293341 & 0.0000 \\
MANAGEMENT & 0.225743 & 0.060215 & 3.748945 & 0.0003 \\
\hline \hline R-squared & 0.857634 & Adjusted R-squared & 0.851659 \\
\hline \hline
\end{tabular}

\section{Insurance Financial variables Analysis with respect to Credit Rating}

The adjusted $\mathrm{R}$ square shows a significant value of 0.8095 . This value shows in this study, the explanatory power of the model. In the model, all of the financial variables show significant values at a $95 \%$ confidence interval.

Table 4: Insurance Financial Variables Analysis with Respect to Credit Rating

\begin{tabular}{lllll}
\hline \hline Variable & Coefficient & Std. Error & t-Statistic & Prob. \\
\hline \hline
\end{tabular}




\begin{tabular}{lllll} 
ASSETQUALITY & 2.037547 & 0.961661 & 2.118779 & 0.0461 \\
EFFICIENCY & 0.803722 & 0.225434 & 3.565216 & 0.0006 \\
LIQUIDITY & 0.097179 & 0.046603 & 2.085259 & 0.0509 \\
PROFITABILITY & 4.964243 & 1.211346 & 4.098122 & 0.0001 \\
\hline \hline R-squared & 0.822737 & Adjusted R-squared & 0.809521 \\
\hline \hline
\end{tabular}

The findings in table 4 regarding the financial variables support the hypothesis and shows a high interconnection of these variables in the rating assignment of the creditworthiness of insurance companies. The same as for financial variables of bank's credit rating applies also for the credit rating of the insurance company. The only exception is that efficiency is leading from liquidity in the insurance's rating assignment.

The analytical results of the study confirm that some of the accounting ratios are specifically, derive the probability of default of any institution and hence, play a vital role in assigning a rating to them. The most contributing and worthy variable to be profitability followed by asset quality and two other variables of the financial institutions. So as there is a significant relationship between independent and dependent variables at $5 \%$ level.

After the consideration of quantitative factors, the second part contributes in the analysis of nonfinancial measures and hence, the obtained analysis results are transparent and clear to inform that non-financial variables are the important determinants of credit rating assignment and influence the credit rating decesion. As the most important and critical part of non-financial objects is corporate governance that is highlighted in the analysis model. However, on the other hand, management does not lag behind significantly. These results are comparable and prove to be claimed that the current model is well fitted and able to catch the underlying principles of credit rating assessment and also prove that the independent variables are factors of insurance company's' rating quality.

In practice, it is to be required the managers and stakeholders to keep in their eyes and also put a careful focus on the operations and determinants (e.g. profitability, asset quality, liquidity and etc.) that help to achieve a good credit rating. Each CRA has its own internal customized risk evaluation process and assessment mechanism that is not a public document and not published by the CRA, which is a support rating system.

With valuable information, this chapter is beneficial for all the managers, investors or other market researchers for their assessment and also help them to adjust business strategies that enable banks and insurance companies in Pakistan a high and best credit rating. Both of the players of the financial sectors seek a right and high credit rating should improve their asset quality, profitability and suggest that the credit rating assessment strongly depends upon the profitability factor.

In the end, this section winds up with the importance of non-financial variables. The study infers that without non-financial variables, rating assessment will consider incorrect and invaluable. So that the non-financial variables improve the powers of a model and the results conclude that corporate governance (non-financial factor), plays a pivotal role while assigning a rating to any financial institute.

\section{Discussion, Conclusion and Recommendations}

The credit ratings and CRAs, both are becoming the most important and essential part of the financial market. Due to the complex procedures of credit rating assessment and many other issues around the role of ratings in financial markets, the current study sets out to examine empirically important aspects of bank and insurance company's credit ratings. This study constitutes the first 
attempt to explore the role of financial and non-financial information in credit ratings.

\section{Summary of Research Findings \\ Financial Categories}

In quantitative measures, profitability is important and is essential for risk evaluation of credit rating and the result are consistent and supported with the results of Shen et al. (2012). For asset quality, it looks that commercial banks and insurance companies want to get high credit rating must pay more attention to asset quality measures and the findings are supported with the reported results of Shen et al. (2012) and Hammer et al. (2012).

The current study concluded that liquidity has a positive relationship with the dependent variable credit rating and it is statistically approved as well and the same is reported and supported by Poon (2003) and Doumpos et al. (2005). Interestingly, Adams et al. (2003) revealed that not only for the CRAs credit risk assessment, liquidity also important for the internal rating system of insurance companies.

\section{Non-financial Categories}

This study concludes that banks and insurance companies operating in Pakistan with weak governance practices are assigned low ratings. This finding is intuitive and consistent with results reported by Boot et al. (2006) and Kick et al. (2011). The key role of the non-financial information to assess the risks is the key management team of any institution. Therefore there was a significant role and impact of management variable across the analysis and influence the credit rating decision.

\section{Conclusion of the Study}

The obtained results of this empirical study support the stated hypothesis and analysis is also consistent with studies conducted previously. Specifically, the analysis of the study shows the importance of quantitative and qualitative measures of creditworthiness of any institution in the assigning of credit rating because of the credit rating procedure. The measurement of the probability of default for any subjected institution comes first for the risk evaluation assignment. The overall results, therefore, reveal that both of the quantitative and qualitative variables contribute to explain the quality work of assigned rating and therefore considered important during the assessment and consistent with findings as reported by Belloti (2011). This study is a knowledge hub and strongly contributes to the credit rating risk assessment evaluation, specifically in the financial and non-financial determinants. The coefficients of the variables show a positive relationship with the dependent variable. The analysis of this study has significant importance, it ensures the importance to reduce default risk FIs pose.

\section{Limitations of the Study}

As there are a number of limitations and constraints for every research work, same as in this study. However, the study analysis was done with full of quality work so that the observed results were not muted but due to some of the specific constraints that intend to be continued and more research work in this area. The more important constraint was that the time frame of research was ten years 2009 -2018 due to the non-availability of data. Moreover, the research work was done on only two sectors from the financial industry of Pakistan. Furthermore, the data is based on the financial statement and time for this study was very short because of the length and depth of the study. In addition, Pakistani credit rating industry is wholly controlled by a couple of agencies. Therefore it was assumed to be an oligopolistic industry in its structure. Hence, the assigned ratings of these two CRAs as well as the analysis and other research work by using the same agencies rating data are argued to be similar and may be the specimen of the whole credit rating industry. 


\section{References}

Adams, M., Burton, B., \& Hardwick, P. (2003). The determinants of credit ratings in the United Kingdom insurance industry. Journal of Business Finance \& Accounting, 30(304), 539572.

Beltratti, A., \& Stulz, R. M. (2012). The credit crisis around the globe: Why did some banks perform better? Journal of Financial Economics, 105(1), 1-17.

Bellotti, T., Matousek, R., \& Stewart, C. (2011). Are rating agencies' assignments opaque? Evidence from international banks. Expert Systems with Applications, 38(4), 4206-4214.

Boot, A.W.A., Milbourn, T.T., \& Schmeits, A. (2006). Credit ratings as coordination mechanisms, The Review of Financial Studies, 19(1), 81-118.

Caouette, J. B., Altman, E. I., \& Narayanan, P. (1998). Managing Credit Risk: The Next Great Financial Challenge. Hoboken, N.J.: Wiley.

Carbone, I., \& Kohn, L. M. (1999). A method for designing primer sets for speciation studies in filamentous ascomycetes. Mycologia, 91(3), 553-556.

Cocheo, S. (2000). Performance picture: avoiding efficiency as a religion. American Bankers Association. ABA Banking Journal, 92(2), S8.

Doumpos, M., \& Pasiouras, F. (2005). Developing and testing models for replicating credit ratings: A multicriteria approach. Computational Economics, 25(4), 327-341.

Etikan, I., Musa, S. A., \& Alkassim, R. S. (2016). Comparison of convenience sampling and purposive sampling. American Journal of Theoretical and Applied Statistics, 5(1), 1-4.

Erkens, D. H., Hung, M., \& Matos, P. (2012). Corporate governance in the 2007-2008 financial crisis: Evidence from financial institutions worldwide. Journal of corporate finance, 18(2), 389-411.

Hammer, P. L., Kogan, A., \& Lejeune, M. A. (2012). A logical analysis of banks' financial strength ratings. Expert Systems with Applications, 39(9), 7808-7821.

Kao, C., Chiang, M. H., \& Baltagi, B. H. (2000). Nonstationary panels, panel cointegration and dynamic panels. Advances in Econometrics, 15, 179-222.

Liao, Y. P., Li, K. F., \& Hung, S. (2017). Does the conflict of interest matter for credit ratings? The impact of the client's economic importance and the CRA tenure. Asia-Pacific Journal of Accounting \& Economics, 24(3-4), 302-322.

Mensah, M. O., Agbloyor, E. K., Harvey, S. K., \& Fiador, V. O. (2017). Sovereign credit ratings and bank funding cost: Evidence from Africa. Research in International Business and Finance, 42, 887-899.

Poon, W. P. (2003). Are unsolicited credit ratings biased downward? Journal of Banking \& Finance, 27(4), 593-614.

Shen, C. H., Huang, Y. L., \& Hasan, I. (2012). Asymmetric benchmarking in bank credit rating. Journal of International Financial Markets, Institutions and Money, 22(1), 171-193. 